Original Article

\section{Timing of corneal stitches removal after extra capsular cataract extraction for control of postoperative astigmatism}

Doaa M. Elmenshawy ${ }^{1}$, Sawsan A. Shalaby ${ }^{2}$, Asmaa M. Gamal ${ }^{2}$

${ }^{1}$ Ophthalmology Department, Dekerness General Hospital, Dakahlia, Egypt.

${ }^{2}$ Ophthalmology Department, Faculty of Medicine for Girls, Cairo, Al-Azhar University, Egypt.

\title{
ABSTRACT
}

Background: There are challenges in cataract surgery to predict the postoperative results and correct them. The source of variability is the change in the corneal shape which leads to surgically induced astigmatism.

Objective: To determine the most appropriate time for removal of corneal stitches after extracapsular cataract extraction surgery (ECCE) as regards the stability of refractive status of the eye.

Methodology: An interventional, randomized controlled clinical trial was conducted on 20 eyes of 20 patients who had ECCE surgery and sutures removal 8 weeks after surgery (group I) and 20 eyes of 20 patients who had ECCE surgery and sutures removal 12 weeks after surgery (group II). Visual outcome was assessed before and after suture removal by refraction and keratometry.

Results: Mean surgically induced astigmatism (SIA) in group (I) was $-5.09 \pm 1.46$ diopter (D) postoperative and $2.14 \pm 0.86 \mathrm{D}$ after $1^{\text {st }}$ suture removal and $-1.786 \pm 0.66 \mathrm{D}$ after all suture removal, there is a statistically significant change of power among group (I). Mean SIA in group (II) was $-5.26 \pm 1.43 \mathrm{D}$ postoperative and $-3.82 \pm 1.78 \mathrm{D}$ after $1^{\text {st }}$ suture removal and $-2.818 \pm 0.73 \mathrm{D}$ after all suture removal, there is a statistically significant change of power among group (II). There is statistically significant higher median power among group II than group I (P=0.001) after 1st suture removal and after full suture removal.

Conclusion: When interrupted 10/0 nylon corneal suture causes a high degree of astigmatism, it is better to be removed at 8 weeks after surgery, not just being as effective in alleviating astigmatism, but safer and more stable in refraction.

JRAM 2021; 2 (2): 158-165

Keywords: ECCE, surgically induced astigmatism, suture removal, timing.

Submission Date: 18 November 2020

Acceptance Date: 29 December 2020.

Corresponding author: Doaa Mohamed Mohamed Elmenshawy, ophthalmology department, Dekerness General Hospital, Dakahlia, Egypt. Tel: 00201061717472. E-mail: doaa9000@gmail.com

Please cite this article as: Elmenshawy DM, Shalaby SA, Gamal AM. Timing of corneal stitches removal after extra capsular cataract extraction for control of postoperative astigmatism. JRAM 2021; 2 (2): 158-165. DOI: 10.21608/jram.2020.49816.1099

\section{INTRODUCTION}

Cataract surgery is most common single surgery performed all over the world. Cataract surgery rates increased due to improvement of techniques. Nevertheless, cataracts remain the major cause of blindness, responsible for 50 percent of blindness among medium and low-income countries [1]. The principal causes of suture and surgically induced astigmatism (SIA) are wound compression, wound gap and wound misalignment which following cataract surgery ${ }^{[2]}$.

Different studies have clarified the importance of the length of the corneal wound, its distance from the limbus, the prevention of lateral wound shift, and the number of sutures used and their type. In addition, the tension in the suture, a loose or absorbable suture tends to cause wound gap, thus resulting in a horizontal

https://jram.journals.ekb.eg

Print ISSN: 2636-252X - Online ISSN: 2636-2538 flattening of the cornea which causes against the rule astigmatism (ATR), and non-absorbable suture that causes the wound to be compressed and the corneal to be vertically extended producing with the rule astigmatism (WTR) ${ }^{[3]}$.

Cutting non absorbable sutures is by far the easiest way to eliminate postoperative astigmatism. This will release any compressive effect, which causes its meridian to become steep. The sutures can be cut using a laser or a blade. Though absorbable sutures induce a compression for short time after the surgery, cutting and removal is usually unnecessary because they are naturally absorbed, damaged or extruded ${ }^{[4]}$.

Indications for suture removal include breakage or loosening of sutures, abscess, astigmatism of 4D or Personal non-commercial use only. JRAM copyright @ 2020. All rights reserved 
greater, hyperopia of 3D or higher. Contraindications include evidence of insufficient wound healing such as wound gaping, wound dehiscence, or inadequate fibrosis to support the wound or high intraocular pressure ${ }^{[5]}$. Sometimes sutures are left in place for one or more years if appropriate astigmatism is reached. However, if breaks occur then removal of the suture becomes a must. Furthermore, catastrophic complications related to sutures such as inflammation, infections, vascularization and sub-epithelial and epithelial erosion and ulceration may also occur ${ }^{[6] .}$ Our study aimed to detect the most appropriate time of sutures removal after ECCE for control of postoperative astigmatism.

\section{SUBJECT AND METHODS \\ Subjects}

An interventional, randomized controlled clinical trial included forty eyes of forty patients dividing into 2 groups, twenty eyes of patients had undergone ECCE surgery and sutures were removed at 8 weeks after surgery (Group I), twenty eyes of patients had undergone ECCE surgery and sutures were removed at 12 weeks after surgery (Group II). Sample size was fifty, but ten cases were excluded from the study as they had too tight sutures resulting in high mean cylinder value and the remaining forty cases were statistically reanalyzed. Patient samples were gathered from Ophthalmology department, Al Zahraa University Hospital Clinics, Al-Azhar University from November 2019 to March 2020.

The ethical review board of Al-Azhar University approved this study and conducted according to Declaration of Helsinki. All the necessary approvals for carrying out the research were obtained. After explaining the study purpose and prior to participating in the study, each participant gave an informed oral consent. Complete confidentiality was ensured for all patients, and they had the rights to refuse to participate without affection of the care given to him/her.

Exclusion criteria: The research had excluded eyes with preoperative corneal scarring, pterygium, corneal degenerative changes, corneal opacities, raised intraocular pressure. Eyes in which the preoperative cylindrical refraction was more than (+/-) 3 diopters .Those in which previous surgery or corneal irregularities disallowed accurate refraction and keratometry, Intraoperative complications like vitreous loss. Postoperative complications like wound leak, raised IOP, Infection, too tight (causing more than 10 $\mathrm{D}$ cylinder) and too loose sutures.

\section{Methods}

Study tools and procedures: History taking (name, sex, age, occupation, past ophthalmic history, medical history). Complete ophthalmic examination including, Landolts visual acuity and converted to decimal. Refractive status using autorefractokeratometere (Nidek ARK 500A Maehama, Hiroishi Gamagori, Aichi 443-0038, Japan). Best corrected visual acuity (BCVA). Slit-lamp microscopic examination, full examination of the anterior segment performed for cornea, sclera, anterior chamber, iris, pupil and lens. Fundus examination by slit-lamp bio microscopy using + 90 D noncontact lens. Ophthalmic biometry using A/B scan Mentor (Minneapolis, Minnesota, USA) ultrasound. Intraocular lens (IOL) power calculation aimed at $-0.50 \mathrm{D}$ refraction postoperative. All patients had undergone routine ECCE $8-10 \mathrm{~mm}$ in length. We performed ECCE through a partial thickness groove incision (about $10 \mathrm{~mm}$ length) at peripheral clear cornea; the incision was made perpendicular to tissues, approximately two-thirds thickness deep. The anterior chamber was entered with a microsurgical knife and then viscoelastic was injected into anterior chamber. A 360 degree can- opener anterior capsulotomy was created with a cystotome. The wound was extended with corneoscleral scissors angling blades at 45 degrees to tissue to create a biplane incision. The nucleus was expressed by applying careful pressure at 6 and 12 o'clock. The cortical material was removed with manual irrigation/aspiration. Viscoelastic was injected into the anterior chamber and capsular bag, and then a single piece PMMA PCIOL was implanted. The wound was carefully closed using 4-5 interrupted 10-0 nylon sutures, which were removed 8-12 weeks postoperatively. Steroid eye drops; Prednisolone acetate $1 \%$ (Allergan, Irvine, United States) every 2 hours, the dose was progressively decreased after 2 weeks) and antibiotic eye drops, Moxifloxacin hydrochloride $0.5 \%$ (Alcon, Geneva, Switzerland) were obtained. Post-operatively After 8 weeks, if there were more than 2.5-cylinder diopters through keratometry and refraction (Fig. 1), patients were randomly assigned to one of two groups after describing the purpose of the procedure and receiving consent.

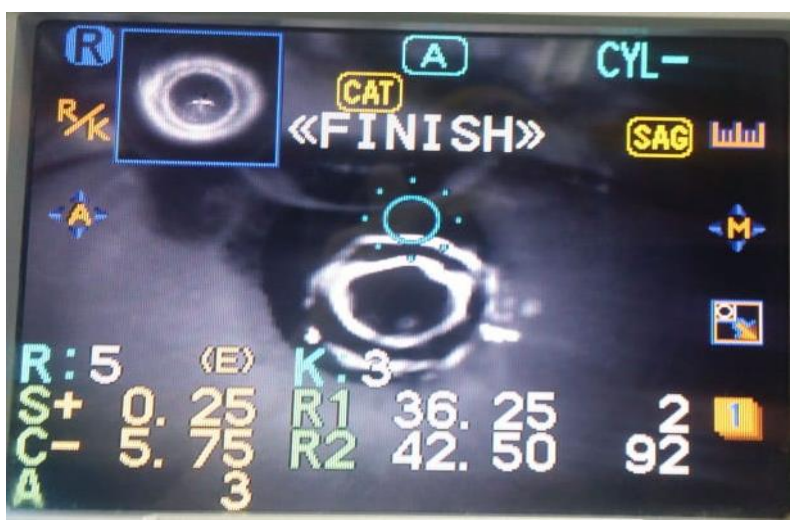

Figure (1): Case with interrupted sutures producing wound compression in the same meridian as the steep keratometry readings.

All surgeries were performed by two experienced surgeons at El Zahraa University Hospital. At 8 and 12 weeks postoperatively, selective single suture removal using blade was done with the removal of the second suture, after 1 hour, in the steepest axis if necessary. If the astigmatism was still 2.5 or higher, a further suture was cut following the same protocol, which was continued based on residual astigmatism a third and a fourth time if necessary. The results were analyzed to 
determine the correct timing after ECCE surgery for suture removal. The prescription of glasses should be delayed 1 week following removal of the final suture.

\section{Statistical Methods}

Data were fed to the computer and analyzed using IBM SPSS Corp. Released 2013. IBM SPSS Statistics for Windows, Version 22.0. Armonk, NY: IBM Corp. Qualitative data were described using number and percent. Quantitative data were described using median (minimum and maximum) for non-parametric data and mean standard deviation for parametric data after testing normality using Shapiro-Wilk test. All Pvalues were based on two-side tests and considered statistically significant when $<0.05$.

\section{Qualitative data}

Chi-Square test for comparison of 2 or more groups. Monte Carlo test for comparison of categorical variables when 2 cells or more have count less than 5 .

\section{Quantitative data between groups}

- Student t-test was used to compare 2 independent groups.

- Mann-Whitney U test was used to compare 2 groups of non-parametric variables.

- Kruskal Wallis test was used to compare more than 2 independent groups with Mann Whitney U test to detect pair-wise comparison.

\section{RESULTS}

In group (I) the mean age was $55.32 \pm 3.46$ years (range $50-60)$. This group included 11 males $(55 \%)$ and 9 females $(45 \%)$. In group (II) the mean age was $56.60 \pm 3.49$ years (range $50-60$ ). This group included 13 males $(65 \%)$ and 7 females $(35 \%)$. There was no statistically significant difference between the two groups regarding age and sex (table 1).

\section{Correlation between keratometric and refractive astigmatism}

There is statistically significant strong positive correlation between keratometric and refractive astigmatism among studied cases $(\mathrm{r}=0.985, \mathrm{p}<0.001)$. This indicates that changes in corneal curvature caused the observed refraction. (Fig. 2)

\section{Types of astigmatism present in each group at 8 weeks}

Overall, 34 cases had with-the-rule (WTR), 2 cases against the rule (ATR), and 4 cases oblique astigmatism. Group I include 18 WTR cases $(90.0 \%)$, 1 ATR $(5.0 \%)$ and 1 oblique $(5.0 \%)$ Group II include 16 WTR cases $(80.0), 1$ ATR $(05.0 \%)$ and 3 oblique cases $(15.0 \%)$ (table 2). For this research purposes, With the rule astigmatism is that subtype which is corrected at $90^{\circ} \pm 30^{\circ}$ by a plus cylinder while against the rule astigmatism is that which is corrected at $180^{\circ} \pm 30^{\circ}$ by a plus cylinder, the remainder $60^{\circ}$ considered oblique astigmatism. (Fig. 3).
Changes in postoperative cylindrical power among and between groups

In group (I), the mean value of cylindrical power by keratometry was $-5.09 \pm 1.46 \mathrm{D}$ postoperative, $2.14 \pm 0.86$ after 1 st suture removal and $-1.786 \pm 0.66 \mathrm{D}$ after all suture removal, there is a statistically significant change of power among group (I) $\mathrm{p} 1<0.001, \mathrm{p} 2<0.001, \mathrm{p} 3<0.001)$. In group (II), the mean value of cylindrical power by keratometry was $5.26 \pm 1.43 \mathrm{D}$ postoperative and $-3.82 \pm 1.78 \mathrm{D}$ after $1 \mathrm{st}$ suture removal and $-2.818 \pm 0.73 \mathrm{D}$ after all suture removal, there is there is a statistically significant change of power among group (II) p1<0.001, $\mathrm{p} 2<0.001, \mathrm{p} 3<0.001$ There is statistically significant higher median power among group II than group I after $1 \mathrm{st}$ suture removal and after full suture removal $(\mathrm{P}=0.001)$. There is no statistically significant difference between studied groups regarding median postoperative power $\mathrm{P}=0.654$.

\section{The percentage change in power, Axis and BCVA between studied groups}

Power: The mean percent change in group (I) was $0.612 \pm 0.20 \%$ and in group (II) was $-0.45 \pm 0.12 \%$. There is a statistically significant difference between studied groups regarding median power change $(\mathrm{P}=0.009)$ (table 4) Axis: The mean percent change in group (I) was $9.42 \pm 12.11 \%$ while in group (II) was $6.29 \pm 12.11 \%$. There is no statistically significant difference between studied groups regarding mean axis change $\mathrm{P}=0.142$. BCVA: The mean percent of change of change in BCVA in group (I) was $1.08 \pm 0.57 \%$, while in group (II) was $0.964 \pm 0.628 \%$. There is no statistically significant difference between studied groups regarding mean BCVA change $\mathrm{P}=0.38$ (table 4)

\section{Change in power percent according to the initial} type of postoperative astigmatism

In group (I): The mean percent of change in power in cases of WTR astigmatism was $0.528 \pm 0.22 \%$ while in cases of ATR astigmatism, it was $0.547 \pm 0.0 \%$ and in cases of oblique astigmatism it was $0.684 \pm 0.0 \%$. There is no statistically significant difference of percent of change in power between different types of astigmatism ( $\mathrm{p}=0.425)$. In group (II): The mean percent of change in power in cases of WTR astigmatism was $0.479 \pm 0.131 \%$ while in cases of ATR astigmatism, it was $0.808 \pm 0.0 \%$ and in cases of oblique astigmatism it was $0.615 \pm 0.0 \%$. there is no statistically significant difference of percent of change in power between different types of astigmatism $(\mathrm{p}=273)$ (table 5). Between group I and II: There is a statistically significant higher mean percent of power change among group I than group II for WTR astigmatism $(\mathrm{p}=0.049)$ and for oblique astigmatism $(\mathrm{p}=0.46)$. While for cases of ATR astigmatism There is a statistically significant higher mean percent of power change among group (II) than group (I) $\mathrm{p}=0.046$ (table 5) 
Table (1): demographic characteristics among studied cases

\begin{tabular}{|c|c|c|c|c|c|}
\hline \multicolumn{2}{|c|}{ items } & $\begin{array}{l}\text { Group I } \\
(\mathbf{n}=\mathbf{2 0})\end{array}$ & $\begin{array}{c}\text { Group II } \\
(\mathbf{n}=\mathbf{2 0})\end{array}$ & Stat. Tests & $p$ value \\
\hline \multicolumn{2}{|c|}{$\begin{array}{ll}\text { Age: } & \text { Mean } \pm \text { SD } \\
& \text { Range }\end{array}$} & $\begin{array}{l}55.32 \pm 3.46 \\
(50.0-60.0)\end{array}$ & $\begin{array}{l}56.60 \pm 3.49 \\
(50.0-60.0)\end{array}$ & $\mathrm{t}=1.30$ & 0.199 \\
\hline Sex & $\begin{array}{l}\text { Male } \\
\text { Female }\end{array}$ & $\begin{array}{c}11(55.0) \\
9(45.0)\end{array}$ & $\begin{array}{c}13(65.0) \\
7(35.0)\end{array}$ & $\chi^{2}=0.739$ & 0.390 \\
\hline Side & $\begin{array}{l}\text { Right } \\
\text { Left }\end{array}$ & $\begin{array}{c}16(80.0) \\
4(20.0)\end{array}$ & $\begin{array}{l}12(60.0) \\
8(40.0)\end{array}$ & $\chi^{2}=0.739$ & 0.390 \\
\hline
\end{tabular}

t: Student $\mathrm{t}$ test $\chi^{2}=$ Chi-Square test

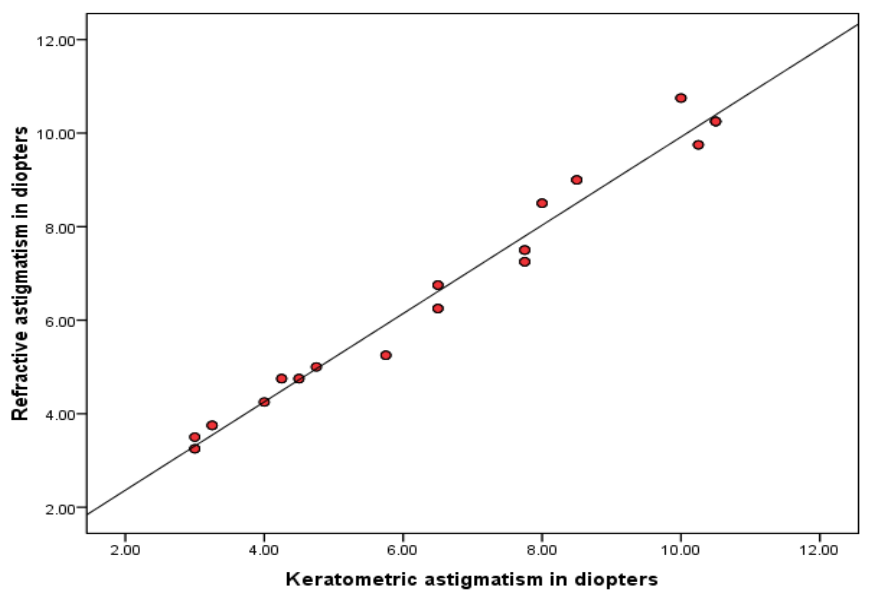

Fig. (2) Scatter diagram representing correlation of degrees of astigmatism as measured by keratometry and refraction

Table (2): Comparison of initial type of postoperative astigmatism between studied groups at 8 Weeks.

\begin{tabular}{|c|c|c|c|c|c|c|}
\hline \multirow{2}{*}{\multicolumn{2}{|c|}{ Groups }} & \multicolumn{3}{|c|}{ Initial type of astigmatism } & \multirow{2}{*}{ Total } & \multirow{2}{*}{$\begin{array}{c}\text { test of } \\
\text { significance }\end{array}$} \\
\hline & & WTR & ATR & Oblique & & \\
\hline Group I & No. $(\%)$ & $18(90.0 \%)$ & $1(5.0 \%)$ & $1(05.0 \%)$ & $20(50.0 \%)$ & $\mathrm{MC}$ \\
\hline Group II & No. $(\%)$ & $16(80.0 \%)$ & $1(05.0 \%)$ & $3(15.0 \%)$ & $20(50.0 \%)$ & $\mathrm{p}=0.295$ \\
\hline Total & No. $(\%)$ & $34(85.0 \%)$ & $2(05.0 \%)$ & $4(10.0 \%)$ & $40(100 \%)$ & \\
\hline
\end{tabular}

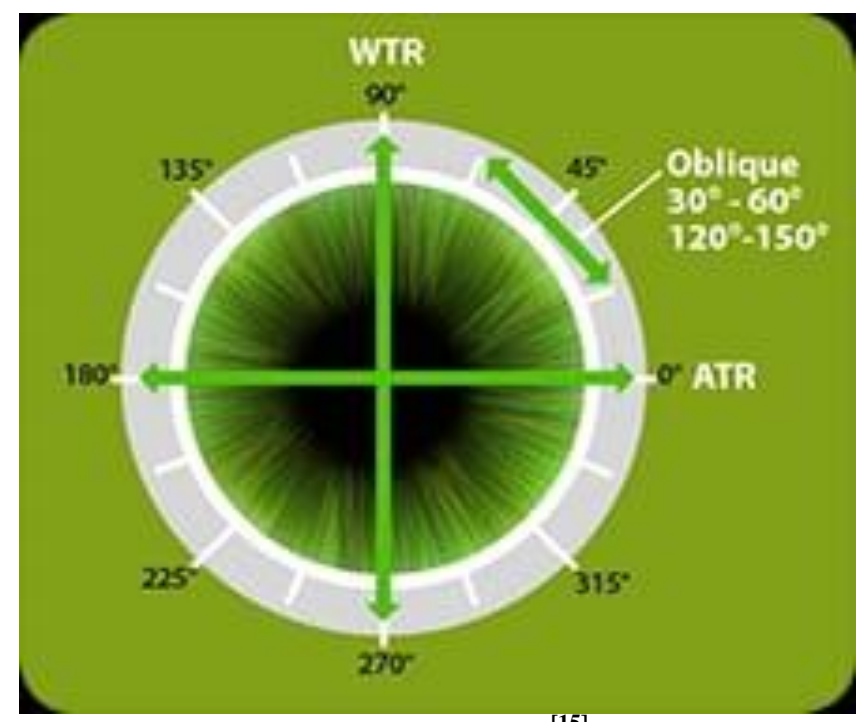

Figure (3): Types of astigmatism ${ }^{[15]}$ 
Table (3): Comparison of cylindrical power mean values between studied groups

\begin{tabular}{|c|c|c|c|c|c|}
\hline \multicolumn{2}{|c|}{ Power in Dioptre } & $\begin{array}{l}\text { Group I } \\
(\mathbf{n}=\mathbf{2 0})\end{array}$ & $\begin{array}{c}\text { Group II } \\
(\mathbf{n}=\mathbf{2 0})\end{array}$ & $\begin{array}{c}\text { Test of } \\
\text { significance }\end{array}$ & $P$ value \\
\hline $\begin{array}{l}\text { Pre suture } \\
\text { removal }\end{array}$ & $\begin{array}{l}\text { Mean } \pm \text { SD } \\
\text { Median } \\
\text { Range }\end{array}$ & $\begin{array}{c}-5.09 \pm 1.46 \\
-5.75 \\
(-3.0--6.5)\end{array}$ & $\begin{array}{c}-5.26 \pm 1.43 \\
-5.5 \\
(-3.0--6.5)\end{array}$ & $\mathrm{Z}=0.449$ & 0.654 \\
\hline $\begin{array}{l}\text { after } 1^{\text {st }} \text { suture } \\
\text { removal }\end{array}$ & $\begin{array}{l}\text { Mean } \pm \text { SD } \\
\text { Median } \\
\text { Range }\end{array}$ & $\begin{array}{c}-2.14 \pm 0.86 \\
-2.25 \\
(-1.0--3.0)\end{array}$ & $\begin{array}{c}-3.82 \pm 1.78 \\
-2.75 \\
(-2.25--5.0)\end{array}$ & $\mathrm{Z}=3.28$ & $0.001 *$ \\
\hline Final & $\begin{array}{l}\text { Mean } \pm \text { SD } \\
\text { Median } \\
\text { Range }\end{array}$ & $\begin{array}{c}-1.786 \pm 0.66 \\
-1.75 \\
(-0.75--2.9)\end{array}$ & $\begin{array}{c}-2.818 \pm 0.73 \\
-2.5 \\
(-3.75--2.0)\end{array}$ & $\mathrm{Z}=3.91$ & $0.001 *$ \\
\hline $\begin{array}{l}\text { Within group } \\
\text { significance }\end{array}$ & & $\begin{array}{l}\text { p1<0.001* } \\
\text { p2<0.001* } \\
\text { p3<0.001* }\end{array}$ & $\begin{array}{l}\mathrm{p} 1<0.001 * \\
\mathrm{p} 2<0.001 * \\
\mathrm{p} 3<0.001 *\end{array}$ & & \\
\hline
\end{tabular}

Z: Mann Whitney U test *statistically significant, P1 : difference between cylindrical power mean values presuture removal and after ${ }^{\text {st }}$ suture removal, P2: difference between cylindrical power mean values presuture removal and final suture removal, P3: difference between cylindrical power mean values after $1^{\text {st }}$ suture removal and after final suture removal, *: p value $<0.05$.

Table (4): Comparison of percentage of change in power, axis and BCVA mean values between studied groups.

\begin{tabular}{|l|l|c|c|c|c|}
\multicolumn{2}{|c|}{ Percent of change } & \multicolumn{1}{c|}{$\begin{array}{c}\text { Group I } \\
(\mathbf{n = 2 0})\end{array}$} & $\begin{array}{c}\text { Group II } \\
(\mathbf{n = 2 0})\end{array}$ & $\begin{array}{c}\text { Test of } \\
\text { significance }\end{array}$ & p value \\
\hline Power & Mean \pm SD & $0.612 \pm 0.20$ & $0.45 \pm 0.12$ & & \\
& Median & 0.79 & 0.46 & $\mathrm{Z}=2.58$ & $0.009 *$ \\
\hline \multirow{2}{*}{ Axis } & Range & $(0.81-0.23)$ & $(0.62-0.24)$ & & \\
& Mean \pm SD & $9.42 \pm 12.11$ & $6.29 \pm 12.11$ & & \\
& Median & 4.80 & 0.104 & $\mathrm{Z}=1.46$ & 0.142 \\
\hline BCVA & Range & $(0.49-32.33)$ & $(0.95-34.0)$ & & \\
& Mean \pm SD & $1.08 \pm 0.57$ & $0.964 \pm 0.628$ & & \\
& Median & 1.03 & 1.0 & $\mathrm{Z}=0.878$ & 0.38 \\
\hline
\end{tabular}

Z: Mann Whitney U test, *: p value< 0.05 .

Table (5): Comparison of Percent of Change in cylindrical power according to initial type of postoperative astigmatism among studied groups.

\begin{tabular}{|c|c|c|c|c|c|}
\hline & \multirow{2}{*}{ Groups } & \multicolumn{3}{|c|}{ Change in power } & \multirow{2}{*}{$\begin{array}{c}\text { test of } \\
\text { significance }\end{array}$} \\
\hline & & WTR & ATR & Oblique & \\
\hline Group I & Mean \pm SD & $0.528 \pm 0.22$ & $0.547 \pm 0.0$ & $0.684 \pm 0.0$ & $\mathrm{KW}, \mathrm{p}=0.425$ \\
\hline Group II & Mean \pm SD & $0.479 \pm 0.131$ & $0.808 \pm 0.0$ & $0.615 \pm 0.0$ & $\mathrm{KW}, \mathrm{p}=273$ \\
\hline \multirow{2}{*}{\multicolumn{2}{|c|}{ Comparison between 2 groups }} & $\mathrm{z}=1.99, \mathrm{p}=0.049 *$ & $\mathrm{z}=2.0, \mathrm{p}=0.046^{*}$ & $\mathrm{z}=2.0, \mathrm{p}=0.046^{*}$ & \\
\hline & & KW: Krauskal Wallis test & \multicolumn{2}{|c|}{ Z: Mann Whitney U test } & \\
\hline
\end{tabular}

\section{DISCUSSION}

In ophthalmology, perhaps no other surgery has undergone such rapid and drastic revolutionary change in the past four decade, as has cataract surgery. The transition from intracapsular cataract extraction (ICCE) to ECCE to phacoemulsification has really been a breakthrough in cataract extraction. ${ }^{[7]}$ One of the most important causes of delayed visual rehabilitation is the surgically induced astigmatism. Therefore, one of the key objectives of current surgical methods is to eliminate surgically induced astigmatism ${ }^{[8]}$.

Although the considerable articles on how to avoid, correct or minimize postoperative astigmatism, the question of the most correct time to remove sutures has only been discussed anecdotally. ${ }^{[9]}$ In cases with a high grade of astigmatism, it is mandatory to balance between early removal when the greatest reduction of astigmatism may be expected but corneal wound healing may not be complete, especially if the patient is still treated with topical steroids, and late removal where wound healing is achieved but a permanent high cylinder may be a risk. ${ }^{[10]}$ Donders, 1864, who declared against the rule astigmatism (ATR) following surgery, first noticed alteration in the shape of the cornea after cataract extraction. This change has been more and more recognized since then, although with modem suture material, the change is typically with the rule. ${ }^{[11]}$

In our study, 40 eyes which had undergone ECCE in which sutures are removed at 8 and 12 weeks respectively, are included, 24 male patients were $(60 \%)$ and 16 female patients were $(40 \%)$; with mean age of the studied groups was 55.32 and 56.6 for group 
I and II respectively. The results of refraction and keratometry shows a statisticaly strong correlation, this means that the observed astigmatism was due to changes in the corneal shape rather than other structures, and this confirms the findings of Kawahara and Takayanag ${ }^{[12]}$ which found that refractive astigmatism and keratometric astigmatism after cataract surgery were strongly correlated.

The results of our study have demonstrated that interrupted nylon sutures typically induced almost with the rule astigmatism $90 \%$ in group I and $80 \%$ in group II. This was in agreement with Elkadim, et al. ${ }^{[13]}$ They found that the most common orientation for postoperative astigmatism was WTR astigmatism. The theory of wound compression in the early postoperative period can clarify this.

According to our results, early selective suture removal has great role in reducing high postoperative WTR astigmatism and giving better visual outcome, this agrees with Sapre and Radadia. ${ }^{[14]}$ and Satitpitakul et al. ${ }^{[5]}$ they found that selective suture cutting on the same day (SSSC) would help patients achieve adequate vision faster and reduce the amount of follow-up visits required after surgery. The type of resulting postoperative astigmatism affects the degree of change in power. In which WTR astigmatism shows a significant decrease when done early while ATR becomes worse if suture removed early as this result in more gaping of the wound. This agrees with Sapre and Radadia. ${ }^{[14]}$; they observed that patients with against the rule astigmatism shows significantly less improvement than other types of patients.

According to our study, eyes with postoperative WTR astigmatism changed to ATR astigmatism and eyes with postoperative ATR become more ATR astigmatism, this agrees with Feizi et al. ${ }^{[4]}$. They noticed that early suture cutting can over time transform WTR astigmatism into undesirable ATR astigmatism.

This study has some limitation such as visual acuity was done using Landolt's Brocken C chart and converted to decimal. Refraction was done using Keratometry and auto refractometry only and not by corneal topography. Astigmatism was calculated be arithmetic method not by vector analysis. Surgeries were done by more than one surgeon; this limitation could introduce bias from the operator, to minimize this bias and to ensure a non-biased study, we strictly defined the study protocol as described in the methods section.

The results of this study recommend that, in the case of interrupted 10/0 nylon corneal suture which caused high with the rule astigmatism, it should be removed 8 weeks after surgery, not only to alleviate the effect of induced astigmatism, but also to be safer and refraction is more stable. We also recommend that glasses better to be prescribed after 4 weeks of final sutures removal, particularly when done in 8 weeks.

\section{CONCLUSION}

At 8 weeks post-operative, selective single suture removal can be performed safely with removal of the second suture in the steepest axis, if necessary, after 1 hour. The prescription for glasses should be postponed for 1 week after removal of the final suture. Early suture cutting can over time transform WTR astigmatism into undesirable ATR astigmatism. ATR astigmatism is better to delay sutures removal to prevent more gaping of the wound. ATR astigmatism is best to postpone the removal of sutures in order to avoid further wound gaping.

Conflict of interest: No conflict of interest

Financial support: this work not funded from any governmental or non-governmental agencies.

\section{REFRENCES}

1. Alshamrani A. Cataracts pathophysiology and managements. The Egyptian Journal of Hospital Medicine, 2018; 70(1): 151-154.

2. Corbett M, Maycock N, Rosen E, and O'Brart D. Cataract surgery. Corneal topography. Edited by Corbett M., Maycock N., Rosen E. and O'Brart D. 2nd Ed. Springer International Publishing, 2019; 2:189199.

3. Binder SP. 2018. Incisions and astigmatism. [https://www.eyeworld.org/]. Accessed September 24, 2020.

4. Feizi S, Javadi M, Behnaz N, Fani-Hanife S, and Jafarinasab MR. Effect of suture removal on refraction and graft curvature after deep anterior lamellar keratoplasty in patients with keratoconus. Cornea, 2018; 37(1): 39-44.

5. Satitpitakul V, Uramphorn $\mathbf{N}$, and Kasetsuwan $\mathbf{N}$. Factors predicting change in corneal astigmatism following suture removal in post-penetrating keratoplasty patients. Clinical Ophthalmology (Auckland, NZ), 2019; 13: 1593.

6. Gibbons A, Sayed-Ahmed I, Mercado C, Chang V, and Karp C. Corneal surgery. Ophthalmology. Edited by Yanoff $M$. and Duker J. 5th Ed. Elsevir health science, 2018; 296-324.

7. Davis G. The evolution of cataract surgery. Missouri medicine, 2016; 113 (1): 58-62.

8. Ming-Yueh L, Hilda T, and Goh P. Surgical induced astigmatism in phaecoemulsification cataract surgery. Asian Journal of Ophthalmology, 2017; 15(3).

9. Hashemi H, Khabazkhoob M, Soroush S, Shariati R, Miraftab M, and Yekta A. The location of incision in cataract surgery and its impact on induced astigmatism. Current opinion in ophthalmology, 2016; 27(1): 58-64.

10. Abib D, Koffi B, François D, Zana D, Pascaline K, Yves O, et al. Comparative evaluation of extra capsular extraction (ECCE) with suture and small incision cataract surgery (SICS) manual without suture in the university hospital of ouake. Open journal of ophthalmology, 2018; 8(03): 171.

11. Matalia J, Panman $\mathbf{P}$, and Ghall P. Comparative analysis of non-absorbable 10-0 nylon sutures with absorbable 10-0 Vicryl sutures in pediatric cataract 
surgery. Indian journal of ophthalmology, 2018; 66(5): 661-664.

12. Kawahara A and Takayanagi Y. Comparison of refractive and keratometric astigmatism after microincision cataract surgery. Journal of Cataract and Refractive Surgery, 2017; 43(8): 1050-1053.

13. Elkadim M, Myerscough $\mathbf{J}$, Bovone $\mathrm{C}$, and Busin M. Astigmatism orientation after deep anterior lamellar keratoplasty for keratoconus and its correlation with preoperative peripheral corneal astigmatism. Cornea, 2020; 39(2): 192-195,
14. Sapre AA, and Radadia, HC. Selective suture removal in astigmatism after conventional cataract surgery. Indian Journal of Clinical and Experimental Ophthalmology, 2018; 4(1): 147-151.

15. Cataract IOLS. 2019. surgical planning for astigmatism management. Myalcon.com. [https://www.myalconstore. com / professional / resources / astigmatism-management/ surgical planning - astigmatism - management]. Accessed November 12, 2020. 


\section{الماخص العربي}

توقيت إزالة الغرز بعد جراحات المياه البيضاء للسيطرة علي لانقطية ما بعد الجراحة

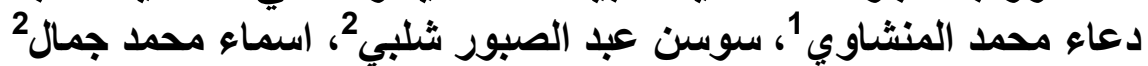

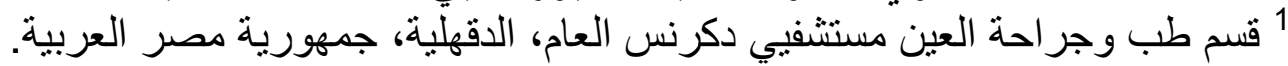

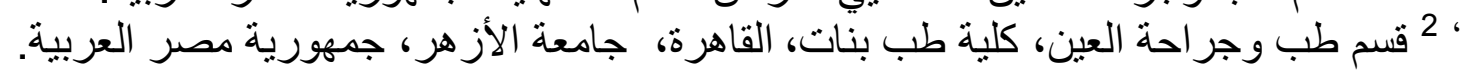

\section{ملخص البحث}

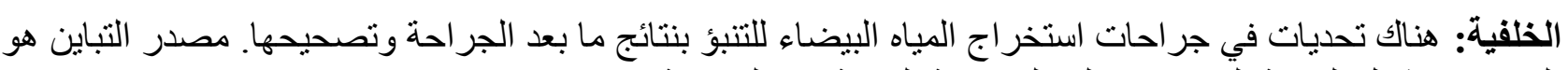

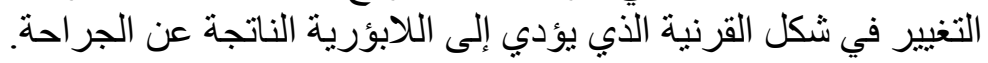

الهدف: تهدف هذه الدراسة الي تحديد أنسب وقت لإزالة غرز القرنية بعد جراحة استخراج المياه البيضاء خارج المحفظة فيما يتعلق باستقر ار الحالة الانكسارية للعين.

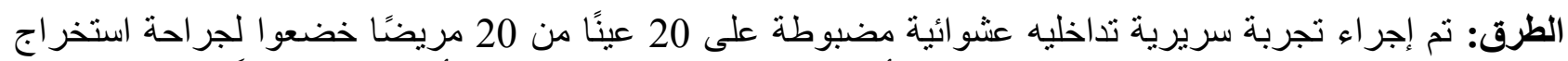

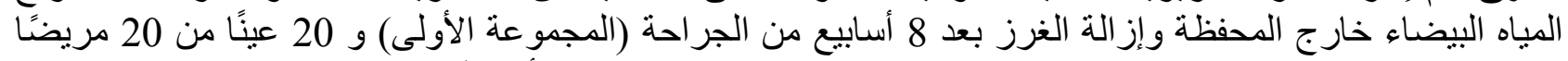

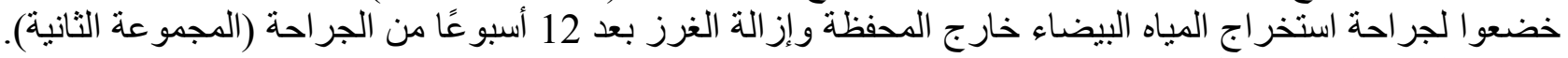
تم تقييم النتائج البصرية قبل وبعد إزالة الخيوط عن طريق الانكسار وقياس تحدب القئ القرنية.

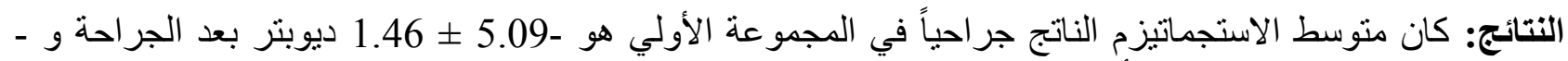

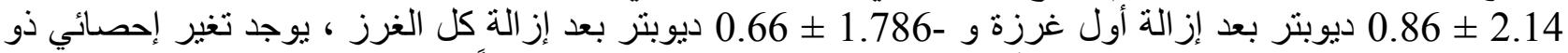

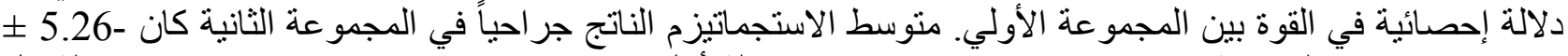

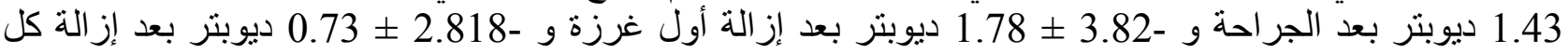

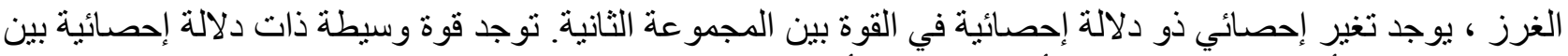

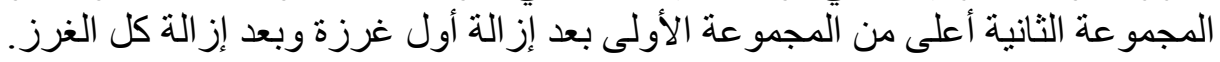

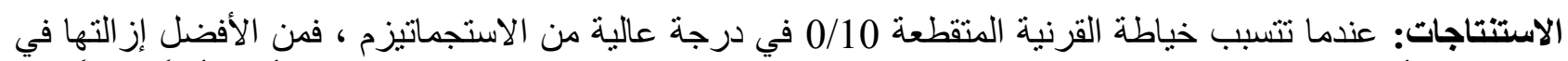

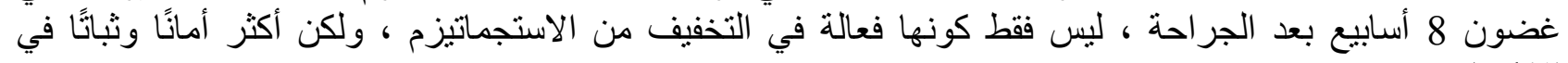
الانكسار.

الكلمات المفتاحية: اللابؤرية المستحثة جر احيًا، ازالة الغرز، توقيت، جر احة استخر اج المياه البيضاء خارج المحفظة.

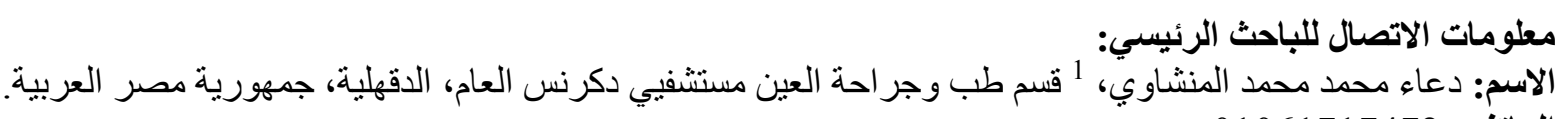
الهاتف: 01061717472 البريد الاكتروني:gmail.com 